\title{
A study of elevated pollution layer over the North China Plain using aircraft measurements
}

DOI:

10.1016/j.atmosenv.2018.07.024

\section{Document Version}

Accepted author manuscript

Link to publication record in Manchester Research Explorer

\section{Citation for published version (APA):}

Liu, Q., Ding, D., Huang, M., Tian, P., Zhao, D., Wang, F., Li, X., Bi, K., Sheng, J., Zhou, W., Liu, D., Huang, R., \& Zhao, C. (2018). A study of elevated pollution layer over the North China Plain using aircraft measurements.

Atmospheric Environment, 190, 188-194. https://doi.org/10.1016/j.atmosenv.2018.07.024

\section{Published in:}

Atmospheric Environment

\section{Citing this paper}

Please note that where the full-text provided on Manchester Research Explorer is the Author Accepted Manuscript or Proof version this may differ from the final Published version. If citing, it is advised that you check and use the publisher's definitive version.

\section{General rights}

Copyright and moral rights for the publications made accessible in the Research Explorer are retained by the authors and/or other copyright owners and it is a condition of accessing publications that users recognise and abide by the legal requirements associated with these rights.

\section{Takedown policy}

If you believe that this document breaches copyright please refer to the University of Manchester's Takedown Procedures [http://man.ac.uk/04Y6Bo] or contact uml.scholarlycommunications@manchester.ac.uk providing relevant details, so we can investigate your claim.

\section{OPEN ACCESS}




\section{A study of elevated pollution layer over the North China}

\section{Plain using aircraft measurements}

Quan Liu ${ }^{\text {a, }}$, Deping Ding ${ }^{\text {a, }}{ }^{*}$, Mengyu Huang ${ }^{\text {a, g }}$, Ping Tian ${ }^{\text {a }}$, Delong Zhao ${ }^{\text {a }}$, Fei

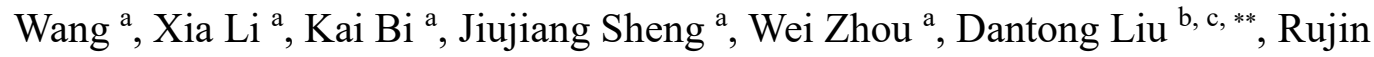
Huang ${ }^{\mathrm{d}}$, Chunsheng Zhao ${ }^{\mathrm{e}}$

a Beijing Weather Modification Office, Beijing Meteorological Bureau, Beijing 100089, China

${ }^{\mathrm{b}}$ Centre for Atmospheric Sciences, School of Earth and Environmental Sciences, University of Manchester, Manchester M13 9PL, UK.

${ }^{\mathrm{c}}$ Department of Atmospheric Sciences, School of Earth Sciences, Zhejiang University, Hangzhou, Zhejiang, China

${ }^{\mathrm{d}}$ Key Laboratory of Aerosol Chemistry and Physics, SKLLQG, Institute of Earth Environment, Chinese Academy of Sciences, Xi'an 710061, China

${ }^{\mathrm{e}}$ Department of Atmospheric Science, School of Physics, Peking University, Beijing 100871, China

${ }_{\mathrm{f}}^{\mathrm{f}}$ Institute of Urban Meteorology, Chinese Meteorological Administration, Beijing 100089, China

${ }^{\mathrm{g}}$ Field experiment base of cloud and precipitation research in North China, China Meteorological Administration, Beijing, 101200, China

${ }^{\text {h }}$ Beijing Key Laboratory of Cloud, Precipitation and Atmospheric Water Resources, Beijing, 100089, China

${ }^{*}$ Corresponding Author. Beijing Weather Modification Office, Beijing Meteorological Bureau, Beijing 100089, China (Deping Ding);

** Corresponding Author. Centre for Atmospheric Sciences, School of Earth and Environmental Sciences, University of Manchester, Manchester M13 9PL, UK.

E-mail addresses: zytddp@vip.sina.com (Deping Ding), dantongliu@gmail.com (Dantong Liu) 


\section{Abstract}

An elevated pollution layer (EPL) at altitude $\sim 1700 \mathrm{~m}$ was observed over the North China Plain (NCP) in November 2016. The vertical profiles of aerosol loadings, chemical compositions and meteorological parameters were in-situ measured at both ground and aircraft platforms. The EPLs were observed simultaneously over Beijing and Baoding city $(\sim 150 \mathrm{~km}$ distance between) with similar aerosol concentration and size distribution, indicating the impact of the EPL at regional scale. The synoptic and remote sensing analysis suggest the pollutants in the EPL may result from regional transport from the polluted southwest, and then elevated by the influence of anticyclone circulation and surrounding terrain. The descent air mass next day may lead to EPL entrainment and contribute to increased aerosol concentration at lower level. The non-refractory compositions measured by aerosol mass spectrometer showed more significant fraction of nitrate and secondary organics in the EPL compared to the other layers. The pollutants in the EPL was then mixed into the developed planetary boundary layer (PBL), leading to uniform distribution of aerosol composition. Such atmospheric stratification at high level and its subsequent impact on the lower level needs to be considered for the future radiative forcing study over this region.

Keywords: elevated pollution layer; aircraft measurement; regional transport; vertical mixing; North China Plain 


\section{Introduction}

Elevated pollution layers have been reported in many cities around the world (Chen et al., 2009; Padmakumari et al., 2013; Shi et al., 2011; Viskanta and Daniel, 1980; Wakimoto and McElroy, 1986). The layers can be formed in a number of ways, such as transport process, evolution of planetary boundary layer (PBL) and local circulation. EPL can be produced by pollutants from tall smoke stacks as high as 380 m (Lusis and Wiebe, 1976). Roger et al. (1986) reported an EPL over Los Angeles with lidar observation, indicating that upper-level winds within the inversion, orographic effects, and thermally induced changes in the depth of the mixed layer controlled the evolution of these layers. Aircraft observations near the foothills of Himalayas suggested that the EPL sources can be from local anthropogenic activities as well as long-range transport (Padmakumari et al., 2013). An EPL at altitudes above $10 \mathrm{~km}$ was also observed over Europe due to long- range transport, which originated from the Pagami Creek forest fire in Minnesota, USA (Dahlkötter et al., 2014). Shi et al., (2011) observed a residual nocturnal layer in the urban atmosphere caused by PBL evolution. EPLs also occurred in China, especially in the North China Plain. Chen et al. (2009) reported an EPL at the altitude of $2500-3500 \mathrm{~m}$ observed by aircraft measurement in Beijing, and suggested that the mountain-valley breeze induced Chimney Effect on EPL formation. Previous studies suggest that EPLs have significant influences on temperature structure and dispersion in the PBL due to their prevention of solar radiation reaching the surface as well as the heating effects in lower atmosphere.

Severe haze events have been frequently observed in the North China Plain (NCP), especially during autumn and winter (Guo et al., 2014; Li et al., 2011; Quan et al., 2013; Zhang et al., 2015; Zheng et al., 2015). Although substantial efforts to reduce anthropogenic emissions during the last decade, Beijing is still experiencing frequent severe haze events (Sun et al., 2016b; Tang et al., 2015; Tao et al., 2016). Previous studies indicated the air pollution in Beijing was not only a local issue but also a regional problem (Hua et al., 2016; Wang et al., 2016; Wu et al., 2017).

The increase of $\mathrm{PM}_{2.5}$ during haze events could be rapid in Beijing. Sometimes the 
mass concentration of $\mathrm{PM}_{2.5}$ could be elevated by an order of magnitude in less than one day (Sun et al., 2016a; Zheng et al., 2015; Zhong et al., 2017). However, the reasons for the rapid formation of such severe haze episodes are still not well understood. Ground observations were found not to be able to fully explain the pollution process, while vertical profiling on the meteorological parameters and aerosol properties could improve the understanding of regional transport influence on heavy pollution events (Hua et al., 2016). By aircraft in-situ measurements, Liu et al. (2009) analyzed 152 vertical profiles of aerosol number concentration and size distribution observed by aircraft-based optical spectrometer probe in Beijing, China, indicating the vertical profiles of aerosol number concentration were influenced by the structures of PBL significantly (Liu et al., 2009). In addition, aerosol vertical profiles could be influenced by weather condition, reginal transport, local circulation, and secondary aerosol formation (Chen et al., 2009; Morgan et al., 2009; Morgan et al., 2010; Zhang et al., 2009).

The objective of this study is to investigate the formation mechanism of the EPL and its impacts on ground aerosol mass concentration and composition, using both ground and aircraft observations, and., and provide an in-depth insight to the high-level regional transport process. Findings of this study would guide the air quality management strategies in the North China Plain.

\section{Description of the measurements}

\subsection{Ground-level observation site}

Comprehensive measurements were conducted in a field campaign at the Baolian meteorological station, China Meteorological Administration (CMA) (39 $56^{\prime} \mathrm{N}$, $\left.116^{\circ} 17^{\prime} \mathrm{E}\right)$. The Baolian station locates between the western 3rd and 4th ring highways in Beijing. The station is about $400 \mathrm{~m}$ away from the main road without significant point sources. A high-resolution time-of-flight aerosol mass spectrometer (HR-ToF-AMS, Aerodyne, USA) was used to measure non-refractory submicron aerosol compositions $\left(\mathrm{NR}-\mathrm{PM}_{1}\right)$ with a time resolution of 5 minutes, including organics, nitrate, sulfate, ammonium, and chloride. Gaseous pollutants including $\mathrm{NO}_{\mathrm{x}}$, 
$\mathrm{SO}_{2}, \mathrm{O}_{3}$ and $\mathrm{CO}$ were measured simultaneously. All instruments were calibrated in the beginning and middle of the project following the standard protocols. A micro-pulse lidar (MPL-4B, Sigmaspace Co., USA) was employed to investigate the evolution of the PBL. The pulse repetition frequency of the MPL is $2500 \mathrm{~Hz}$, at the wavelength of $532 \mathrm{~nm}$. The peak value of the optical energy of laser beam is $8 \mathrm{~mJ}$. The pulse duration was set to $100 \mathrm{~ns}$, and the pulse interval was $200 \mathrm{~ns}$, corresponding to a spatial resolution of $30 \mathrm{~m}$. The measurements of Wind-Profile-Radar and automatic meteorological observation (Vaisala Milos520, Finland) were conducted to obtain wind profiles and meteorological parameters (pressure, temperature, humidity, wind).

\subsection{Details of flight observation}

\subsubsection{Flight routes}

The aircraft (Yun-12 and KingAir-350) were used to carry out vertical profiles in November 2016. The typical aircraft speed is about 180 and $250 \mathrm{~km} \mathrm{~h}^{-1}$ for Yun-12 and KingAir-350 respectively, and the ascent and descent rates during profile was $\sim 2-5 \mathrm{~m} \mathrm{~s}^{-1}$. The surrounding terrain and three-dimensional flight routes during this campaign are shown in Fig. 1. The Yun-12 aircraft took off and climbed to about $3000 \mathrm{~m}$ over the Shahe airport, which located in the north of Beijing city with distance of $35 \mathrm{~km}$. Then the aircraft flew towards southwest for about $150 \mathrm{~km}$ reaching Baoding area and performed vertical profiles in step levels of $300 \mathrm{~m}$ (from 2700 to 600 meters). Meanwhile, the KingAir-350 performed the vertical profiles over Beijing. Before taking off, all instruments were operated for 1-2 hours to measure aerosols on ground. As the Shahe airport is not for commercial use, there are only a few flight operations per day. The effect of aircraft emissions was therefore minor in contributing to the measured vertical distributions of aerosols. The detailed information of vertical profiles in this study is summarized in Table 1. 

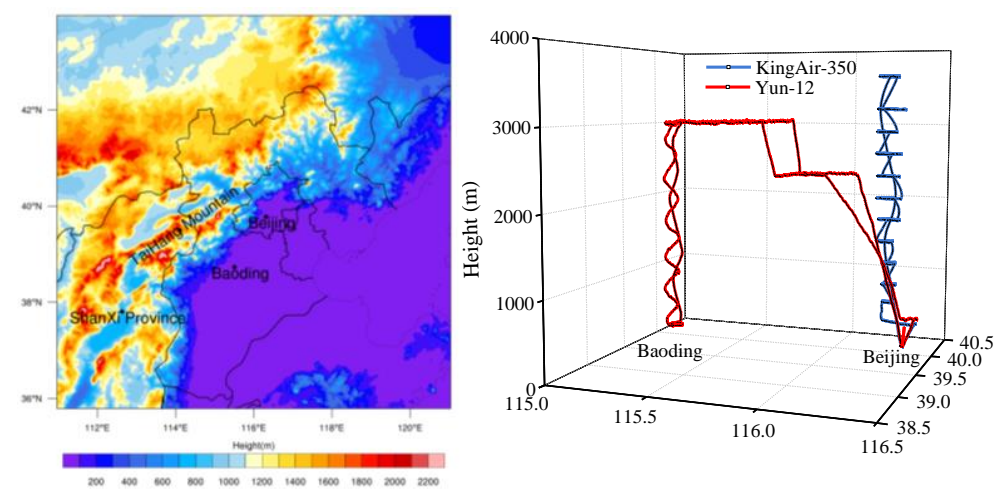

Figure 1. Surrounding terrain and flight routes of aircraft measurements in this study.

Table 1. Information on flight routes

\begin{tabular}{llcl}
\hline Aircraft & Location & $\begin{array}{c}\text { Profile } \\
\text { time }\left(\mathbf{L T}^{\mathbf{a}}\right)\end{array}$ & Instruments \\
\hline Yun-12 & Beijing & $10: 10$ & PCASP, \\
& Baoding & $11: 15$ & Aimms \\
& Beijing & $15: 00$ & \\
\hline KingAi & Beijing & $10: 15$ & AMS, Aimms \\
r-350 & Beijing & $15: 00$ & \\
\hline
\end{tabular}

${ }^{a} \mathrm{LT}$ is the local time.

\subsubsection{Instruments on the aircraft}

In this study, the aerosol number concentration, size distribution and chemical composition were all measured. A passive cavity aerosol spectrometer probe (PCASP, DMT, USA) was mounted on the Yun-12 aircraft wingtip to measure aerosol size distribution ranging $0.1-3.0 \mu \mathrm{m}$ in $1 \mathrm{~Hz}$. The PCASP was maintained every year. and was calibrated using polystyrene latex (Duke Scientific Corporation) on monthly basis during field observations. A Compact time-of-flight aerosol mass spectrometer (C-ToF-AMS, abbreviated as AMS) was mounted in the KingAir-35er cabin to measure submicron non-refractory aerosol $\left(\mathrm{NR}-\mathrm{PM}_{1}\right)$ chemical compositions with the time resolution of 1 minute, including nitrate (NO3), sulfate (SO4), ammonium (NH4), chloride (Chl) and organics (Org). The sample air was introduced into the aircraft cabin through the isokinetic aerosol sampling inlet (Model 1200, BMI CO.) and was split to the AMS sampling line using dedicated stainless-steel flow splitters (Hermann et al., 2001). The operation of AMS is detailed in previous publications (DeCarlo et 
(Aimms-20, Advantech Research Inc.) was used to measure aircraft location, temperature, relative humidity, barometric pressure and wind.

In addition, the ambient pressure may have impacts on the AMS performance, such as the sample flow rate, particle transmission in aerodynamic lens and flight velocity in sizing chamber. To avoid these effects, a pressure controller was mounted upstream of the AMS inlet and maintained at fixed pressure during flight (Bahreini et al., 2008). To keep the flow rate constant, the fixed pressure should be lower than the pressure at the maximum flight height. In this work, the pressure controller was set to $650 \mathrm{hPa}$ and all calibrations (flowrate, particle velocity, ionization efficiency) were performed under this pressure before and after each flight.

\subsubsection{AMS Data process}

Standard ToF-AMS data analysis software packages (SQUIRREL version 1.50) were used to deconvolve mass spectrum and obtain mass concentrations of chemical components. Mass concentrations derived from the AMS are reported as micrograms per standard cubic metre $(T=273.15 \mathrm{~K}, p=1013.25 \mathrm{hPa})$, with the time resolution of 1 min. The AMS collection efficiency (CE), which accounts for the incomplete detection of aerosol species due to particle bounce at the vaporiser and/or the partial transmission of particles by the lens (Canagaratna et al., 2007), is significantly modulated by particle phase (Matthew et al., 2008). In this study, we used a CE correction following the principle developed by Middlebrook et al. (2012). Ionization efficiency (IE) calibrations were performed regularly by using size-selected (300nm) pure ammonium nitrate particles before and after each flight during the observation period. The comparison of submicron aerosol mass concentrations derived by AMS and PCASP showed high consistency (Fig. S1).

A Positive Matrix Factorisation (PMF) analysis was performed on the organic mass spectral dataset following the procedures by Ulbrich et al. (2009). The application of PMF to AMS OA spectra has been described in detail previously (Ulbrich et al., 2009; Zhang et al., 2011). In this study, organic aerosol (OA) were differentiated into hydrocarbon-like organic aerosol (HOA) and oxygenated organic aerosol (OOA), 
corresponding to primary $\mathrm{OA}(\mathrm{POA})$ and secondary $\mathrm{OA}(\mathrm{SOA})$, respectively. The factor solution analysis and mass spectra of HOA and OOA are shown in the supplementary material (Fig. S2).

\section{Results and Discussion}

\subsection{Observed EPL}

Two research flights were performed in the Nov. 15 morning and afternoon respectively. The profiles of atmospheric thermodynamic parameters (the potential temperature $\theta$ and water mixing ratio $q$ ) and aerosol concentration by the PCASP are shown in Fig. 2. The vertical profile of aerosol number concentration as a function of altitude may approximately satisfy an exponential decline function (Liu et al., 2009). The vertical profile of aerosol concentrations showed a distinct elevated pollution layer (EPL) existing between 1700-2000 $\mathrm{m}$ at $\sim 10: 10$ in Nov. 15 morning over Beijing (Fig. 2a). The EPL is defined as the layer at which an increase of aerosol concentration by $\sim 60 \%$ than that in the layer below $(500-1500 \mathrm{~m})$. Chen et al. (2009) observed an EPL at the altitude of 2500-3500 m based on aircraft measurement in 2007 summer over Beijing, when the formation of the EPL resulted from the so-called mountain chimney effect. Note that the elevated concentration in the EPL only occurred in this specific high level but not the convective boundary layer below, and the concentration of the entire atmospheric column was low the day before (Fig. 3f). The EPL observed in this study was thus unlikely to be importantly contributed by local emission through convective mixing or from the nocturnal residue layer the day before. The reason causing this layer may be therefore caused by reginal transport which will be further analyzed in the following. 

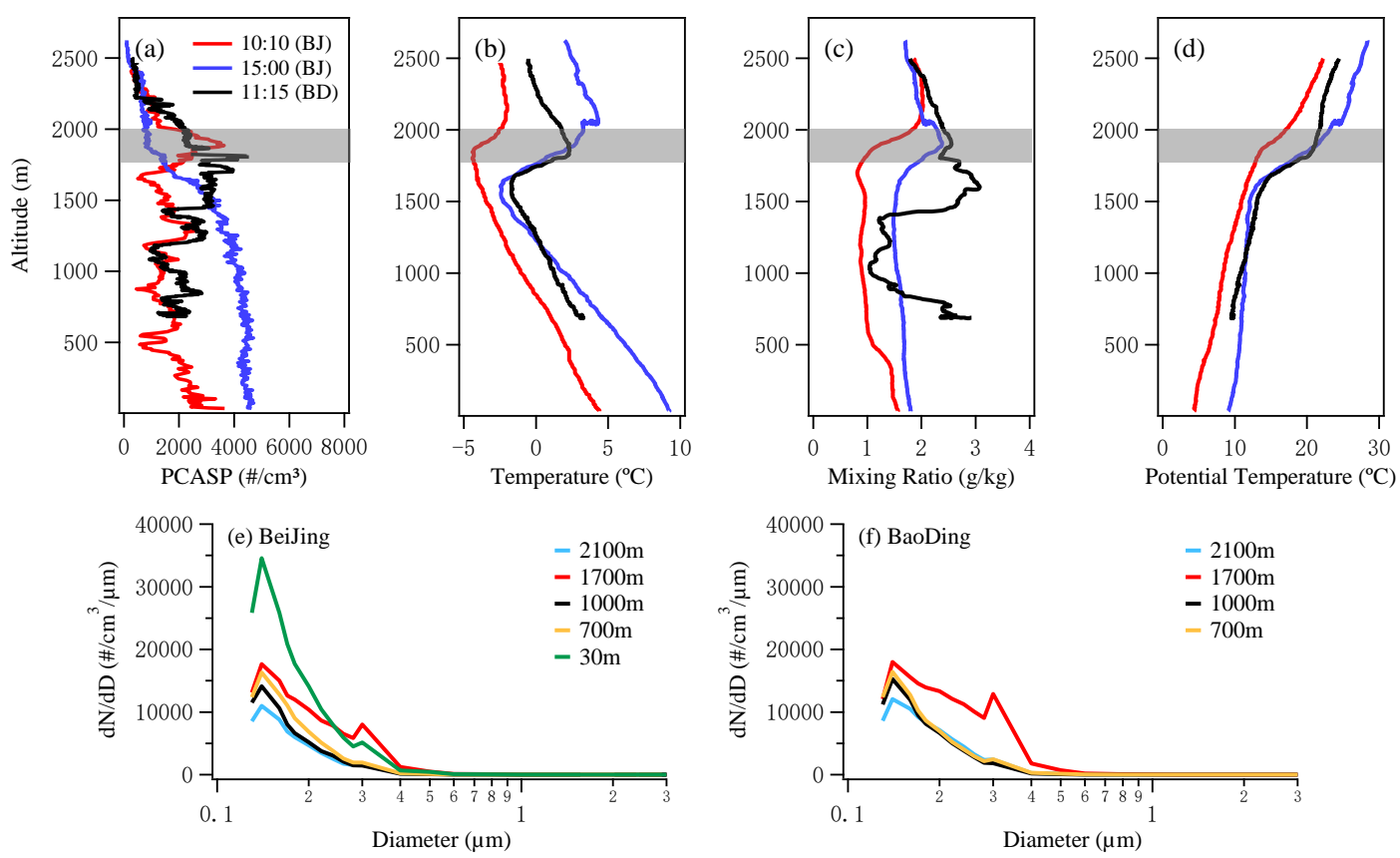

Figure 2. The results of aircraft measurement over Beijing and Baoding, including profiles of (a) aerosol number concentration, (b) temperature, (c) water mixing ratio, (d) potential temperature, and (e-f) aerosol size distribution at different altitudes. Grey overlays in (a-d) present the location of the EPL

For all flights, the $\theta$ showed weak variation up to certain altitude and increased at higher level which can be used to identify the convective mixing (Antonia and Luxton, 1971). The height of planetary boundary layer (PBL) is defined as the altitude (z) at which the vertical gradient $\mathrm{d} \theta / \mathrm{d} z$ reached $5 \mathrm{~K} / \mathrm{km}$, and with the PBL the $\mathrm{d} \theta / \mathrm{d} z$ was less than $5 \mathrm{~K} \mathrm{~km}^{-1}$ denoting a thermal-dynamically well mixed layer (Su et al., 2017). The determined PBL height was $\sim 1600 \mathrm{~m}$ (Fig. S3) at 15:00 in Nov. $15^{\text {th }}$, which was consistent with the PBL height from the lidar retrieval (Fig. 3a). There was usually a temperature inversion at the top of the PBL to depress the EPL mixing to the free troposphere (Fig. 2b). The water mixing ratio in Nov. $15^{\text {th }}$ morning also showed a significant increase in the EPL (Fig. 2c).

The vertical measurement over Baoding area (150 km southwest of Beijing) was performed at 11:15. The vertical profile over Baoding showed similar aerosol properties with that over Beijing measured at 10:10. The EPL was also observed over 
Baoding but the level was slightly lower than that in Beijing (Fig. 2a). The peak aerosol number concentration in Baoding EPL $\left(\sim 4500 \# / \mathrm{cm}^{3}\right)$ was higher than that in Beijing EPL $\left(\sim 3900 \# / \mathrm{cm}^{3}\right)$. The aerosol number size distributions at $2100 \mathrm{~m}, 1700 \mathrm{~m}$, $1000 \mathrm{~m}$ and $700 \mathrm{~m}$ over Beijing and Baoding area are shown in Fig. 2(e-f). The size distributions at $1700 \mathrm{~m}$ (in the EPLs) over Beijing and Baoding had similar peak diameter at $\sim 0.3 \mu \mathrm{m}$, contrasting with the other altitudes. The high consistency for the aerosol features as observed in the EPL over both Beijing and Baoding suggested that the EPLs may result from the transport process in regional scale.

\subsection{The formation of the EPL}

Fig. 3(a) showed the temporal evolution of PBL structure measured by the lidar instrument. The PBL height from lidar is determined at the altitude where a sudden decrease of extinction coefficient occurred and the PBL could be derived from a large gradient in aerosol concentration between the PBL and free troposphere (Boers and Eloranta, 1986; Brooks, 2003). The PBL height was shown be to higher than $2 \mathrm{~km}$ at noon of Nov. $14^{\text {th }}$, indicating a well mixing condition. A notable EPL between 1.5-1.7 $\mathrm{km}$ was observed by the lidar at Nov. $14^{\text {th }}$ midnight and persisted to Nov. $15^{\text {th }}$ morning. The EPL observed by lidar was also captured by aircraft measurements. In addition, the nocturnal EPL in Nov. $14^{\text {th }}$ was formed outside the PBL (Fig. 3a). Before the EPL formation at Nov. $14^{\text {th }}$ midnight, the aerosol concentrations were significantly low throughout the atmospheric column. After 9:00 AM Nov. 15 $5^{\text {th }}$, the PBL height increased rapidly. When the PBL height reached to $\sim 1.7 \mathrm{~km}$ at noontime, the pollutants of the EPL were mixed with the developed PBL. The vertical wind direction profile also showed notable downward mixing during that time (Fig. 3c). The air mass forward trajectories in Nov. $14^{\text {th }}$ were calculated by using the HYSPLIT 4.9 (Hybrid Single-Particle Lagrangian Integrated Trajectory) Model (Draxler and Rolph, 2003) with meteorological dataset from Air Resources Laboratory GDAS (Fig. S4). The trajectories starting height was set to $200 \mathrm{~m}$. The air mass firstly moved to the south of Beijing in the Nov. $14^{\text {th }}$ morning. Then the air mass direction was channeled by the TaiHang Mountain (Fig. 1) with a distinct elevation. The elevated air 
mass then moved back to Beijing with the height of $\sim 1600 \mathrm{~m}$. The wind directions at $\sim 1600 \mathrm{~m}$ also showed a shift from north to south during the EPL formation period (Fig. 3b). The MODIS AOD (aerosol optical depth, AOD) spatial distribution over the North China Plain in Nov. $14^{\text {th }}$ and $15^{\text {th }}$ (Fig. S5) showed a significantly higher aerosol loadings at the southwest Beijing compare to local Beijing area before EPL formation, but hereafter the elevated aerosol loadings were distributed over a large region covering the Beijing area. This suggests the strong regional transport event during the formation of the EPL, with the origin of pollutants mainly stemming from the polluted southwest. This pattern of regional transport as channeled by the mountains was also consistent with the previous studies (Hua et al., 2016; Wu et al., 2017).

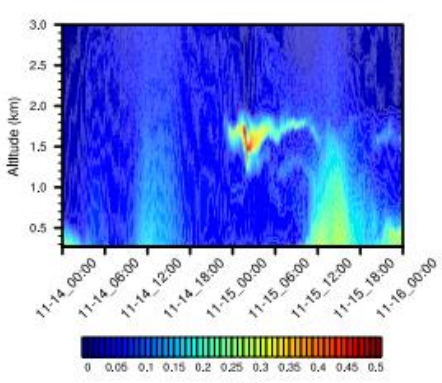

(a)

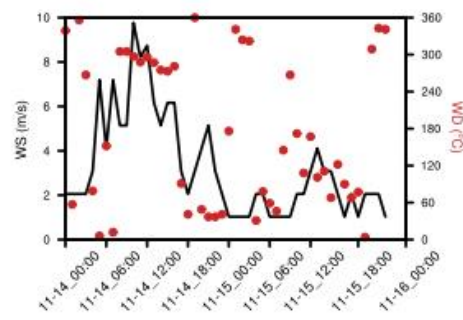

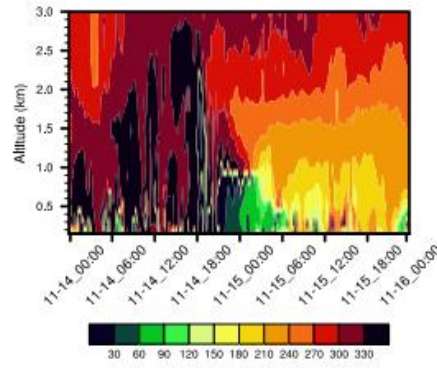

(b)

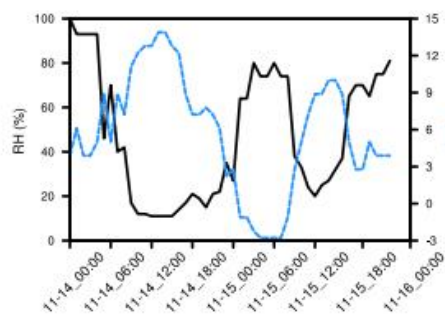

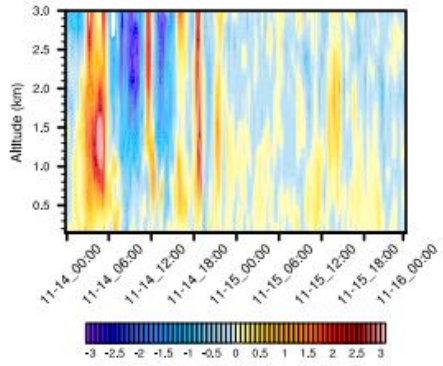

(c)

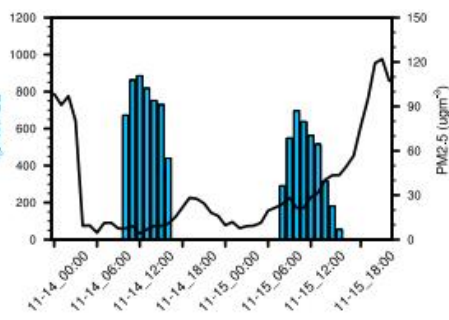

(f)

Figure 3. Variations of meteorological parameters and $\mathrm{PM}_{2.5}$ during the observation. (a) vertical profile of extinction coefficient, (b) horizontal wind direction profile, (c) vertical profile of wind vertical direction and speed, (d) wind speed and direction on the ground, (e) relative humidity and temperature on the ground, (f) direct radiation and $\mathrm{PM}_{2.5}$ mass concentration.

The wind profiles were consistent with synoptic pattern. Fig. 4 showed that in Nov. 15 the anti-cyclonic circulation centered over Henan province at 02:00 (UTC+8). Beijing located at the rear of high-pressure ridge at that time, experiencing with the southwesterly air flow. The eastward high-pressure system strengthened the 
southwesterly air flow. The $925 \mathrm{hPa}$ synoptic pattern showed that Beijing was located in the center of anti-cyclonic circulation at 02:00 in Nov. $15^{\text {th }}$, corresponding to a stagnant condition and low wind speed. The high-pressure ridge caused weak downward motion above $850 \mathrm{hPa}$ layer and the high pressure center led to a weak upward motion at surface layer. This was also consistent with the wind lidar profiles, which showed a convergence of upward and downward air flow at $\sim 1600 \mathrm{~m}$ in early morning of Nov. 15 (Fig. 3c). Such balance between upward and downward wind may maintain the pollutants transported from the southwest within the EPL. In addition, we have also found out two more EPL events using Lidar measurement in 2016 Nov. $21^{\text {th }}$ and Nov. 29 $9^{\text {th }}$ (Fig. S6). These two EPLs are found to be also associated with southwest synoptic air flow at the height where EPL occurred (Fig. S7). Therefore, it can be concluded that our observations in this study could be a general feature for the vertical profile over the NCP region.
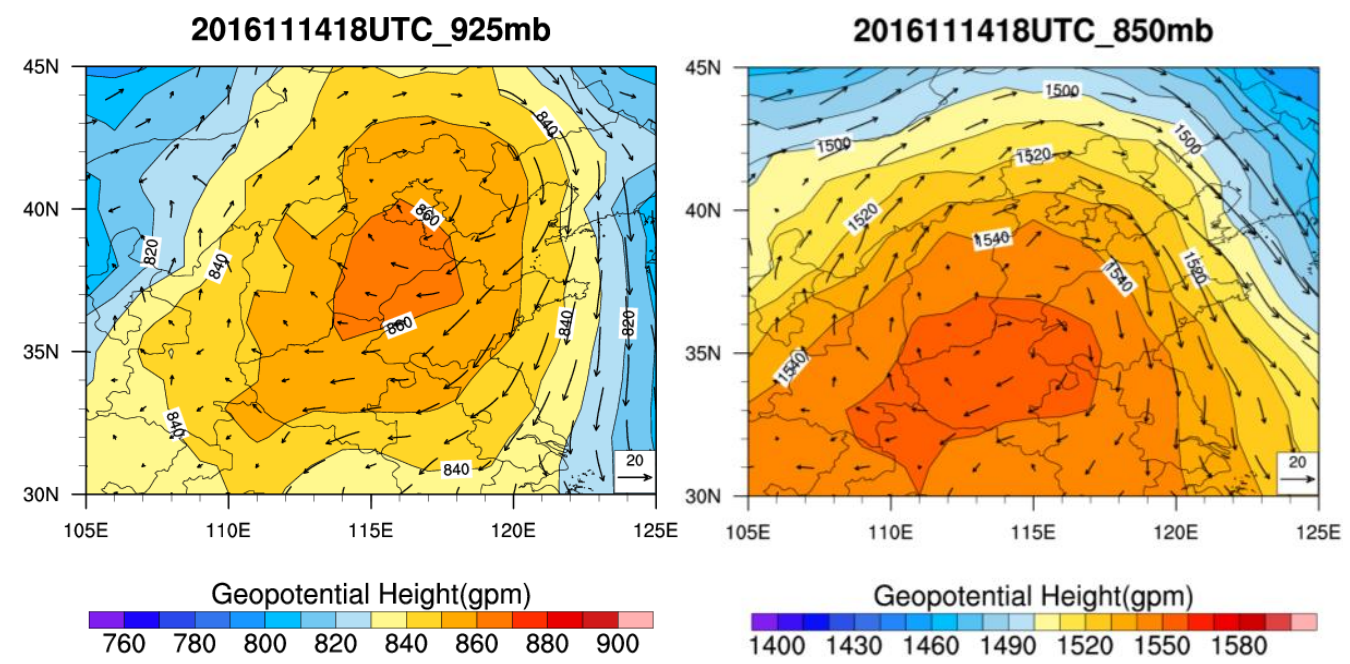

Figure 4. Wind field and pressure chart at geopotential pressure $925 \mathrm{hpa}$ and $850 \mathrm{hpa}$ at 02:00 in Nov. $15^{\text {th }}(\mathrm{LT}=\mathrm{UTC}+8$ hours $)$.

\subsection{Ground measurements}

The ground meteorological parameters and $\mathrm{PM}_{2.5}$ during the observation period are shown in Fig. 3(d-f). In the morning of Nov. 14th, strong northwest wind brought clean air to Beijing and $\mathrm{PM}_{2.5}$ concentration was significantly reduced. The wind speed was then decreased and pollutants began to increase. As shown in Fig. 3(f), the $\mathrm{PM}_{2.5}$ concentration rapidly elevated from $\sim 25 \mu \mathrm{g} \mathrm{m}{ }^{-3}$ at noon to $\sim 120 \mu \mathrm{g} \mathrm{m}^{-3}$ at 
midnight in Nov. 15, by an order of about 5 within half day. Given the surface emissions had no apparent difference between the consecutive two days, the variation of $\mathrm{PM}_{2.5}$ at night (18:00 - 24:00) in Nov. 14 did not show similar variation with that in Nov. 15. The mean wind speed in Nov. 15 was $1.8 \mathrm{~m} \mathrm{~s}^{-1}$. Such weak surface winds were unfavorable for regional transport at ground level. In the following day of EPL formation, the downward wind (the blue color in Fig. 3c) extended further towards the surface, which may bring the pollutants in the EPL to the lower level, thus the rapid increase of surface $\mathrm{PM}_{2.5}$ concentration may be contributed by both entrainment of the EPL and fresh local emission.
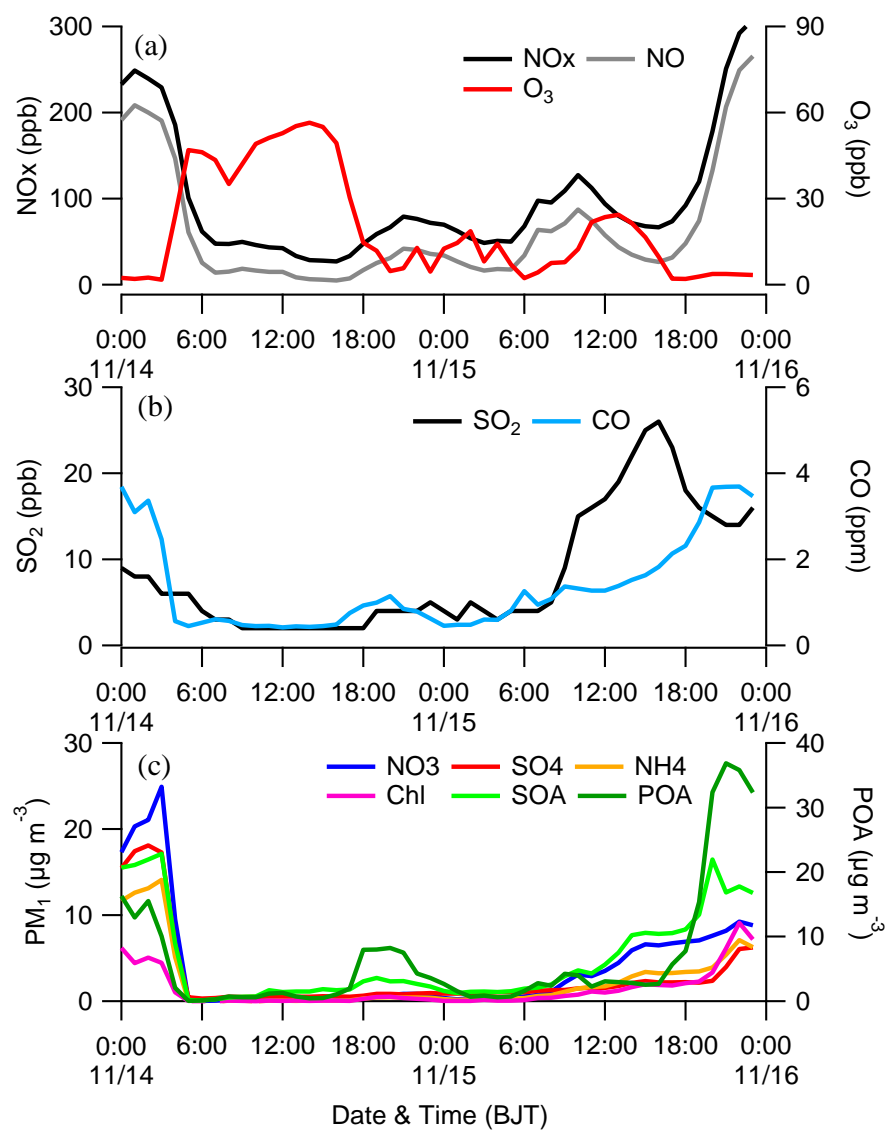

Figure 5. Time series of pollutants on the ground. (a) $\mathrm{NO}_{\mathrm{x}}$ and $\mathrm{O}_{3}$, (b) $\mathrm{SO}_{2}$ and $\mathrm{CO}$, (c) aerosol chemical components.

The time series of precursor gas $\left(\mathrm{NO}_{\mathrm{x}}, \mathrm{SO}_{2}, \mathrm{CO}, \mathrm{O}_{3}\right)$ and aerosol chemical components (NO3, SO4, NH3, Chl and Org) for ground measurement are shown in Fig. 5. Organics was identified as POA (mainly from traffic and cooking emissions) and SOA (secondary formation) by the PMF analysis on organics mass spectra (the 
PMF procedures are detailed in supplement). In Nov. 15 nighttime (18:00-24:00), the concentrations of primary pollutants (NO and POA) increased more rapidly compared to secondary pollutants (NO3, SO4, NH4 and SOA), suggesting the local fresh emissions may contribute more in that time. The local emissions and surface wind speeds had little difference at night between Nov. 14 and Nov. 15, but the nocturnal NO and POA varied significantly between both days. The downward airflow motion extended to the surface layer in Nov. 15 nighttime (Fig. 3c), compressing fresh emissions near the surface and leading to a rapid growth of primary pollutants.

In addition, through past decades efforts of environmental management and control, the $\mathrm{SO}_{2}$ emissions in Beijing decrease to a comparatively low level (Xu et al., 2017). $\mathrm{Wu}$ et al. (2018) identified the southwest transport route of $\mathrm{SO}_{2}$ in the NCP region, and pointed out the primary contributors to $\mathrm{SO}_{2}$ in the southwest were from power plants and steel companies. $\mathrm{Xu}$ et al. (2014) observed frequent noontime $\mathrm{SO}_{2}$ concentration peaks in Beijing, which were principally attributed to down mixing of elevated pollution layer. Our results show a distinct $\mathrm{SO}_{2}$ elevation (such as compared to $\mathrm{CO}$ ) after the EPL formation event, i.e. increased from 10:00 in Nov. 15 and peaked at 15:00 (Fig. 5b). Consistent with the downward wind direction after EPL formation (Fig. 3c), the $\mathrm{SO}_{2}$ containing in the EPL may have contributed to the elevated surface $\mathrm{SO}_{2}$ concentration after the pollutants in the EPL was vertically mixed downwards. In addition, the air mass back trajectories also displayed a distinct downward motion from $\sim 1600 \mathrm{~m}$ to surface during the $\mathrm{SO}_{2}$ increasing period (Fig. S4).

\subsection{The chemical compositions}

The vertical profiles of non-refractory compositions measured by the AMS are shown in Fig. 6. The nitrate and SOA dominated aerosol mass loadings in the EPL, while POA and SOA were dominant components at ground level in the morning Outside the PBL, the fraction of sulfate had a significant enhancement. The nitrate and SOA concentrations on the ground had the most significant increase during the fully developed PBL period (similar to $\mathrm{SO}_{2}$ ). The vertical mixing of aerosol species in the PBL was more homogenous in the afternoon at 15:00 (Fig. 6b), when the pollutants 
in the EPL may have been mixed with surface emissions. The non-refractory aerosol concentration at 15:00 in the EPL was increased by folder of about 2 compared to that at 10:15, consistent with the PCASP measurements (Fig 2a).
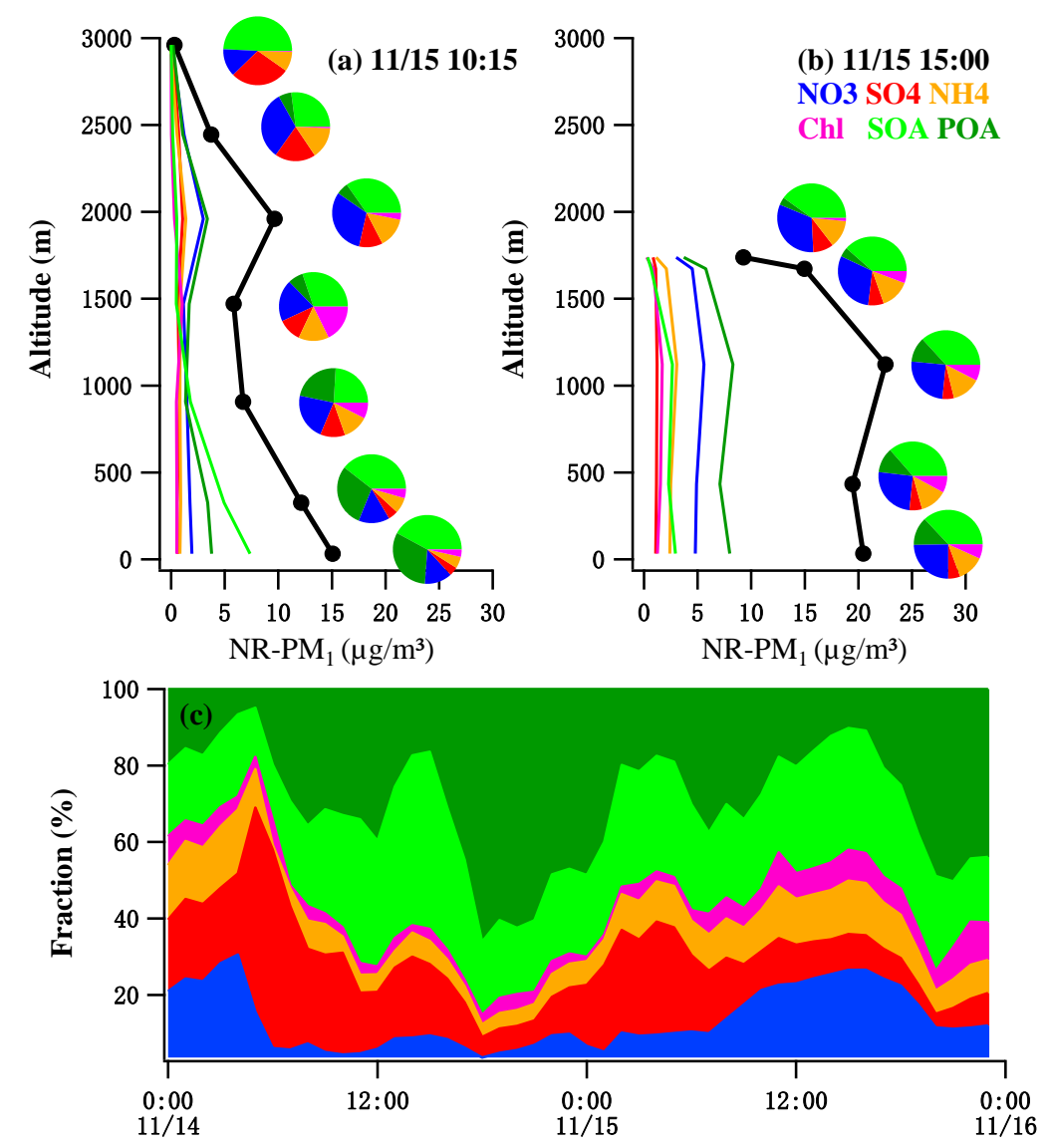

Figure 6. Evolution of aerosol chemical composition: (a-b) in vertical direction, and (c) temporal changes on the ground.

Large reductions in radiative fluxes at the surface during haze events would decrease surface temperature and reduce PBL height (Ding et al., 2013; Qiu et al., 2017; Wang et al., 2014). The measured hourly direct radiation shown in Fig. 3(f) indicated a lower solar radiation received by the surface. The integrated solar direct radiation in Nov. 15 was $3746 \mathrm{~W} \mathrm{~m}^{-2}$, which decreased to $1412 \mathrm{~W} \mathrm{~m}^{-2}$ by $20 \%$ compared to that in Nov. 14. This may be partly because the entrainment from the EPL brought enhanced aerosol concentration throughout the layer, preventing the solar radiation reaching the surface. In addition, the $\mathrm{O}_{3}$ peak concentration in Nov. 15 was lower than that in Nov. 14 which may result from the decrease of photochemical 
reaction rate due to reduced solar radiation.

\section{Summary}

An elevated pollution layer (EPL) at the height of 1700m was observed over Beijing in 2016 Nov. 15, basing on ground lidar and aircraft measurements. Meanwhile the ground $\mathrm{PM}_{2.5}$ mass concentration increased by 5 times in several hours. The increase of aerosol concentration in the EPL was formed simultaneously over Beijing and Baoding region with similar features, such as number concentration and size distribution, indicating the EPL may result from an identical transport process in regional scale. The synoptic and remote sensing analysis suggested the pollutants in the EPL may result from regional transport from the polluted southwest, and then elevated by the influence of anticyclone circulation and surrounding terrain. The descent air flow following in the next day may lead to the entrainment of the EPL and contributed to the increased aerosol concentration at lower level.

Aircraft-based aerosol mass spectrometer (AMS) measurements were performed for the first time in China. The results showed large variation of aerosol chemical compositions with altitude. In the morning, nitrate and SOA were dominant components in EPL, and POA and SOA dominated the total aerosol mass on the ground. The pollutants in the EPL were then mixed into the fully developed PBL, leading to uniform distribution of aerosol compositions. The evolution of aerosol chemical compositions in vertical direction suggested the downward mixing of pollutants from the EPL to the surface. Such atmospheric stratification at high level and its subsequent impact on the lower level need to be considered for the radiative forcing study over this region.

\section{Acknowledgments}

This work was supported by National Key Research and Development Program of China (No. 2016YFA0602001, No. 2016YFC0203302, and No. 2017YFC0209604), the National Natural Science Foundation of China (No. 41505129 and No. 41675138), 
401 and the Beijing Natural Science Foundation (No. 8164058)

402 


\section{Reference}

Bahreini, R., Dunlea, E.J., Matthew, B.M., Simons, C., Docherty, K.S., DeCarlo, P.F., Jimenez, J.L., Brock, C.A., Middlebrook, A.M., 2008. Design and Operation of a Pressure-Controlled Inlet for Airborne Sampling with an Aerodynamic Aerosol Lens. Aerosol Science and Technology 42, 465-471.

Boers, R., and Eloranta, E. W., 1986. Lidar measurements of the atmospheric entrainment zone and the potential temperature jump across the top of the mixed layer. Boundary-Layer Meteorology, 34, 357-375.

Brooks, I. M., 2003. Finding boundary layer top: Application of a wavelet covariance transform to lidar backscatter profiles. Journal of Atmospheric and Oceanic Technology, 20, 1092-1105.

Canagaratna, M.R., Jayne, J.T., Jimenez, J.L., Allan, J.D., Alfarra, M.R., Zhang, Q., Onasch, T.B., Drewnick, F., Coe, H., Middlebrook, A., Delia, A., Williams, L.R., Trimborn, A.M., Northway, M.J., DeCarlo, P.F., Kolb, C.E., Davidovits, P., Worsnop, D.R., 2007. Chemical and microphysical characterization of ambient aerosols with the aerodyne aerosol mass spectrometer. Mass Spectrom. Rev. 26, 185-222.

Chen, Y., Zhao, C., Zhang, Q., Deng, Z., Huang, M., Ma, X., 2009. Aircraft study of Mountain Chimney Effect of Beijing, China. Journal of Geophysical Research 114.

Dahlkötter, F., Gysel, M., Sauer, D., Minikin, A., Baumann, R., Seifert, P., Ansmann, A., Fromm, M., Voigt, C., Weinzierl, B., 2014. The Pagami Creek smoke plume after long-range transport to the upper troposphere over Europe \&ndash; aerosol properties and black carbon mixing state. Atmospheric Chemistry and Physics 14, 6111-6137.

DeCarlo, P.F., Kimmel, J.R., Trimborn, A., Northway, M.J., Jayne, J.T., Aiken, A.C., Gonin, M., Fuhrer, K., Horvath, T., Docherty, K.S., Worsnop, D.R., Jimenez, J.L., 2006. Field-Deployable, High-Resolution, Time-of-Flight Aerosol Mass Spectrometer. Anal. Chem. 78, 8281-8289.

Ding, A.J., Fu, C.B., Yang, X.Q., Sun, J.N., Petäjä, T., Kerminen, V.M., Wang, T., Xie, Y., Herrmann, E., Zheng, L.F., Nie, W., Liu, Q., Wei, X.L., Kulmala, M., 2013. Intense atmospheric pollution modifies weather: a case of mixed biomass burning with fossil fuel combustion pollution in eastern China. Atmospheric Chemistry and Physics 13, 10545-10554.

Draxler, R. R., Rolph, G. D., 2003. HYSPLIT (Hybrid Single-Particle Lagrangian Integrated Trajectory). NOAA Air Resources Laboratory, Silver Spring, MD. Model access via NOAA ARL READY Website. http://www.arl.noaa.gov/ready/hysplit4.html.

Guo, S., Hu, M., Zamora, M.L., Peng, J., Shang, D., Zheng, J., Du, Z., Wu, Z., Shao, M., Zeng, L., Molina, M.J., Zhang, R., 2014. Elucidating severe urban haze formation in China. Proceedings of the National Academy of Sciences of the United States of America 111, 17373-17378.

Hermann, M., Stratmann, F., Wilck, M., Wiedensohler, A., 2001. Sampling Characteristics of an Aircraft-Borne Aerosol Inlet System. Journal of Atmospheric and Oceanic Technology 18, 7-19. 
Hua, Y., Wang, S., Wang, J., Jiang, J., Zhang, T., Song, Y., Kang, L., Zhou, W., Cai, R., Wu, D., Fan, S., Wang, T., Tang, X., Wei, Q., Sun, F., Xiao, Z., 2016. Investigating the impact of regional transport on PM2.5 formation using vertical observation during APEC 2014 Summit in Beijing. Atmospheric Chemistry and Physics 16, 15451-15460.

Jimenez, J.L., Jayne, J.T., Shi, Q., Kolb, C.E., Worsnop, D.R., Yourshaw, I., Seinfeld, J.H., Flagan, R.C., Zhang, X., Smith, K.A., Morris, J.W., Davidovits, P., 2003. Ambient aerosol sampling using the Aerodyne Aerosol Mass Spectrometer. J. Geophys. Res. 108, 8425.

Li, W., Zhou, S., Wang, X., Xu, Z., Yuan, C., Yu, Y., Zhang, Q., Wang, W., 2011. Integrated evaluation of aerosols from regional brown hazes over northern China in winter: Concentrations, sources, transformation, and mixing states. Journal of Geophysical Research 116.

Liu, P., Zhao, C., Zhang, Q., Deng, Z., Huang, M., Xincheng, M.A., Tie, X., 2009. Aircraft study of aerosol vertical distributions over Beijing and their optical properties. Tellus Series B-chemical \& Physical Meteorology 61, 756-767.

Lusis, M.A., Wiebe, H.A., 1976. The rate of oxidation of sulfur dioxide in the plume of a nickel smelter stack. Atmospheric Environment 10, 793-798.

Matthew, B.M., Middlebrook, A.M., Onasch, T.B., 2008. Collection Efficiencies in an Aerodyne Aerosol Mass Spectrometer as a Function of Particle Phase for Laboratory Generated Aerosols. Aerosol Sci. Technol. 42, 884-898.

Morgan, W.T., Allan, J.D., Bower, K.N., Capes, G., Crosier, J., Williams, P.I., Coe, H., 2009. Vertical distribution of sub-micron aerosol chemical composition from North-Western Europe and the North-East Atlantic. Atmos. Chem. Phys. 9, 5389-5401.

Morgan, W.T., Allan, J.D., Bower, K.N., Highwood, E.J., Liu, D., McMeeking, G.R., Northway, M.J., Williams, P.I., Krejci, R., Coe, H., 2010. Airborne measurements of the spatial distribution of aerosol chemical composition across Europe and evolution of the organic fraction. Atmos. Chem. Phys. 10, 4065-4083.

Padmakumari, B., Maheskumar, R.S., Morwal, S.B., Harikishan, G., Konwar, M., Kulkarni, J.R., Goswami, B.N., 2013. Aircraft observations of elevated pollution layers near the foothills of the Himalayas during CAIPEEX - 2009. Quarterly Journal of the Royal Meteorological Society $139,625-638$.

Qiu, Y., Liao, H., Zhang, R., Hu, J., 2017. Simulated impacts of direct radiative effects of scattering and absorbing aerosols on surface layer aerosol concentrations in China during a heavily polluted event in February 2014. Journal of Geophysical Research: Atmospheres 122, 5955-5975.

Quan, J., Gao, Y., Zhang, Q., Tie, X., Cao, J., Han, S., Meng, J., Chen, P., Zhao, D., 2013. Evolution of planetary boundary layer under different weather conditions, and its impact on aerosol concentrations. Particuology 11, 34-40.

Shi, G., Zhang, D., Wang, B., Chen, B., Yamada, M., Niu, H., 2011. Elevated aerosol layer 
embedded with aged soot particles in a polluted urban atmosphere. Atmospheric Chemistry \& Physics Discussions 11.

Su, T., Li, J., Li, C., Xiang, P., Lau, A.K.-H., Guo, J., Yang, D., Miao, Y., 2017. An intercomparison of long-term planetary boundary layer heights retrieved from CALIPSO, ground-based lidar, and radiosonde measurements over Hong Kong. Journal of Geophysical Research: Atmospheres 122, 3929-3943.

Sun, Y., Chen, C., Zhang, Y., Xu, W., Zhou, L., Cheng, X., Zheng, H., Ji, D., Li, J., Tang, X., Fu, P., Wang, Z., 2016a. Rapid formation and evolution of an extreme haze episode in Northern China during winter 2015. Scientific reports 6, 27151.

Sun, Y., Wang, Z., Wild, O., Xu, W., Chen, C., Fu, P., Du, W., Zhou, L., Zhang, Q., Han, T., 2016 b. "APEC Blue": Secondary Aerosol Reductions from Emission Controls in Beijing. Scientific Reports 6.

Tang, G., Zhu, X., Hu, B., Xin, J., Wang, L., Münkel, C., Mao, G., Wang, Y., 2015. Impact of emission controls on air quality in Beijing during APEC 2014: lidar ceilometer observations. Atmospheric Chemistry \& Physics 15, 12667-12680.

Tao, M., Chen, L., Wang, Z., Wang, J., Tao, J., Wang, X., 2016. Did the widespread haze pollution over China increase during the last decade? A satellite view from space. Environmental Research Letters 11, 054019.

Ulbrich, I.M., Canagaratna, M.R., Zhang, Q., Worsnop, D.R., Jimenez, J.L., 2009. Interpretation of organic components from Positive Matrix Factorization of aerosol mass spectrometric data. Atmospheric Chemistry and Physics 9, 2891-2918.

Viskanta, R., Daniel, R.A., 1980. Radiative Effects of Elevated Pollutant Layers on Temperature Structure and Dispersion in an Urban Atmosphere. Journal of Applied Meteorology 19, 53-70.

Wakimoto, R.M., McElroy, J.L., 1986. Lidar Observation of Elevated Pollution Layers over Los Angeles. Journal of Climate and Applied Meteorology 25, 1583-1599.

Wang, J., Wang, S., Jiang, J., Ding, A., Zheng, M., Zhao, B., Wong, D.C., Zhou, W., Zheng, G., Wang, L., 2014. Impact of aerosol-meteorology interactions on fine particle pollution during China's severe haze episode in January 2013. Environmental Research Letters 9, 094002.

Wang, Q., Huang, R.-J., Cao, J., Tie, X., Shen, Z., Zhao, S., Han, Y., Li, G., Li, Z., Ni, H., Zhou, Y., Wang, M., Chen, Y., Su, X., 2016. Contribution of regional transport to the black carbon aerosol during winter haze period in Beijing. Atmospheric Environment 132, 11-18.

Wu, F.C., Xie, P., Li, A., Mou, F., Chen, H., Zhu, Y., Zhu, T., Liu, J., Liu, W., 2018. Investigations of Temporal and Spatial Distribution of Precursors $\mathrm{SO}_{2}$ and $\mathrm{NO}_{2}$ Vertical Columns in North China Plain by Mobile DOAS. Atmospheric Chemistry and Physics 18, 1535-1554.

Wu, J., Li, G., Cao, J., Bei, N., Wang, Y., Feng, T., Huang, R., Liu, S., Zhang, Q., Tie, X., 2017. Contributions of trans-boundary transport to summertime air quality in Beijing, China. Atmospheric Chemistry and Physics 17, 2035-2051.

Xu, W.Y., Zhao, C.S., Ran, L., Lin, W.L., Yan, P., Xu X.B., 2014. $\mathrm{SO}_{2}$ noontime-peak phenomenon in the North China Plain. Atmospheric Chemistry and Physics 14, 7757-7768. 
Xu, W., Song, W., Zhang, Y., Liu, X., Zhang, L., Zhao, Y., Liu, D., Tang, A., Yang, D., Wang, D., 2017. Air quality improvement in a megacity: implications from 2015 Beijing Parade Blue pollution control actions. Atmospheric Chemistry \& Physics 17, 1-45.

Zhang, Q., Jimenez, J., Canagaratna, M., Ulbrich, I., Ng, N., Worsnop, D., Sun, Y., 2011. Understanding atmospheric organic aerosols via factor analysis of aerosol mass spectrometry: a review. Analytical and Bioanalytical Chemistry 401, 3045-3067.

Zhang, Q., Ma, X., Tie, X., Huang, M., Zhao, C., 2009. Vertical distributions of aerosols under different weather conditions: Analysis of in-situ aircraft measurements in Beijing, China. Atmos. Environ. 43, 5526-5535.

Zhang, X.Y., Wang, J.Z., Wang, Y.Q., Liu, H.L., Sun, J.Y., Zhang, Y.M., 2015. Changes in chemical components of aerosol particles in different haze regions in China from 2006 to 2013 and contribution of meteorological factors. Atmospheric Chemistry and Physics 15, $12935-12952$.

Zheng, G.J., Duan, F.K., Su, H., Ma, Y.L., Cheng, Y., Zheng, B., Zhang, Q., Huang, T., Kimoto, T., Chang, D., Pöschl, U., Cheng, Y.F., He, K.B., 2015. Exploring the severe winter haze in Beijing: the impact of synoptic weather, regional transport and heterogeneous reactions. Atmospheric Chemistry and Physics 15, 2969-2983.

Zhong, J., Zhang, X., Dong, Y., Wang, Y., Wang, J., Zhang, Y., Che, H., 2017. Feedback effects of boundary-layer meteorological factors on explosive growth of PM2.5 during winter heavy pollution episodes in Beijing from 2013 to 2016. 